\title{
Direct identification of small sequence changes in chromosomal DNA
}

(Genomic DNA sequencing; tRNA mutations; yeast gene replacement; oligodeoxynucleotide primer extension; dideoxynucleotides)

\author{
Jon M. Huibregtse and David R. Engelke* \\ Department of Biological Chemistry, The University of Michigan, Ann Arbor, MI 48109 (U.S.A.) Tel. (313)763-0641
}

(Received January 28th, 1986)

(Revision received and accepted March 10th, 1986)

\section{SUMMARY}

Dideoxynucleotide chain termination sequencing has been applied directly to genomic DNA templates by annealing radiolabeled oligodeoxynucleotide primers to unique sites in total yeast DNA and extending with avian myoblastosis virus (AMV) reverse transcriptase. The technique is used here to confirm the introduction of selectively altered tRNA genes into the Saccharomyces cerevisiae genome by gene replacement.

\section{INTRODUCTION}

To study the expression of chromosomal genes that have been cloned and selectively altered in vitro, it is best to replace them in their original chromosomal environment. In yeast this can be achieved through gene replacement (Scherer et al., 1979; Rothstein, 1983; Shortle et al., 1984) if it is possible to select for uptake and retention of the DNA

\footnotetext{
* To whom correspondence and reprint requests should be addressed.

Abbreviations: AMV, avian myoblastosis virus; bp, base pair(s); ddNTP, dideoxynucleotide triphosphate; dNTP, deoxynucleotide triphosphate; $\Delta$, deletion; IVS, intervening sequence; $k b$, kilobases or $1000 \mathrm{bp}$; MLV, murine leukemia virus; nt, nucleotide(s); oligo, oligodeoxynucleotide; PA, polyacrylamide; SDS, sodium dodecyl sulfate; WT, wild type.
}

segment of interest. In our studies we wished to replace one copy of a tRNA ${ }_{3}^{\text {Leu }}$ gene with a variety of altered copies. To do this we used DNA fragments (Fig. 1) carrying the mutant tRNA gene and the naturally adjacent gene for $\beta$-isopropylmalate dehydrogenase $(L E U 2)$ to transform a haploid yeast strain with a double lesion in LEU2 (leu2-3, leu2-112). Colonies were selected for retention of the WT LEU2 gene by growth in the absence of environmental leucine, but it was necessary to directly assess the presence and copy number of the phenotypically silent tRNA gene mutations. Instead of insertion of a single copy of the tRNA ${ }^{\text {Leu }}-L E U 2$ DNA fragment and elimination of the original genes, it was possible that: (a) the new DNA and the original copy were both retained, (b) multiple copies of the new DNA were inserted, or (c) the original tRNA ${ }_{3}^{\text {Leu }}$ gene was retained with the WT LEU2 gene 
because of recombination between the two loci. In addition, it was possible that second-site mutations had occurred in the tRNA sequence that would invalidate conclusions regarding the effects of the desired mutations. A simple method was therefore devised which could be used to screen transformants for retention of only the new tRNA gene and to confirm the DNA sequence.

\section{EXPERIMENTAL AND DISCUSSION}

(a) Yeast transformation with tRNA ${ }_{3}^{\text {Leu }}$ gene variants

All of the altered tRNA ${ }_{3}^{\text {Leu }}$ genes used in this study contained an $\mathrm{A} \rightarrow \mathrm{T}$ transition in the anticodon and one or more of the other mutations shown in Fig. 1. The recombinant plasmids carrying these genes and the wild type $L E U 2$ gene were linearized with the restriction endonuclease $S a l I$ and used to transform the haploid yeast strain DC5 (leu2-3, leu2-112, can1-11; obtained from Cold Spring Harbor Laboratory). SalI cleavage provided one free end of yeast DNA with which to direct insertion into the yeast chromosome, but there were no restriction sites upstream from the tRNA gene with which to entirely remove the pUC9 DNA. Discrete replacement of the tRNA gene therefore depended on recombination within the yeast sequences immediately upstream from the tRNA gene. This probably accounted for the relatively low efficiency of our transformations (less than ten colonies per plate).
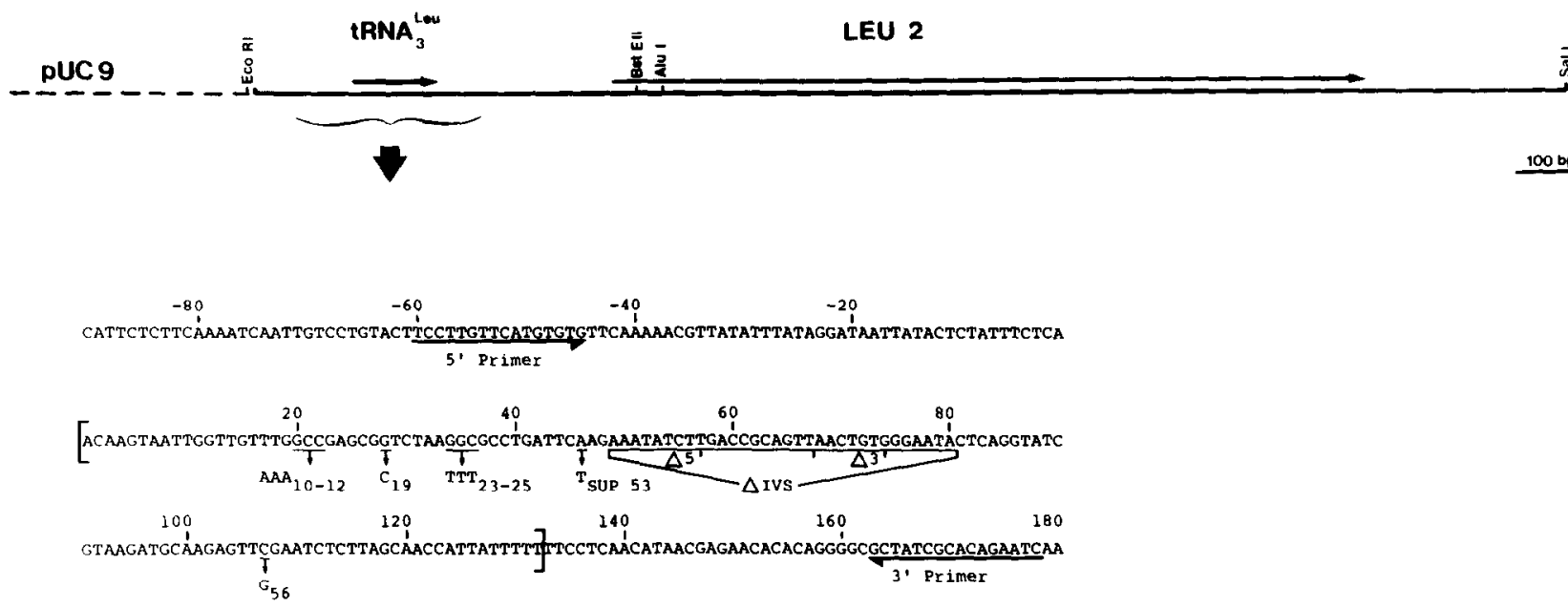

Fig. 1. Structure of the cloned tRNA ${ }_{3}^{\text {Leu}}-L E U 2$ DNA fragment used for yeast transformations. The plasmid DNA used for the gene replacement studies consisted of an XhoI-SalI DNA fragment from chromosome III of $S$. cerevisiae containing $L E U 2$ and either WT or mutated tRNA Leu genes inserted between the SmaI and SalI sites of pUC9 (Vieira and Messing, 1982). The DNA sequence (Andreadis et al., 1982) corresponding to the tRNA ${ }_{3}^{\text {Leu }}$ primary transcript (Engelke et al., 1985) is enclosed in square brackets. Positions are numbered with respect to the first $\mathrm{nt}$ in the primary transcript, but $\mathrm{nt}$ substitutions are numbered as originally published (Newman et al., 1983) according to standardized tRNA positions. Each altered tRNA gene contained an $A \rightarrow T$ transition in the anticodon becoming the tRNA Leu ST3 $_{3}$ amber suppressor (Reed and Leibman, 1979) and one or more of the other mutations indicated. Mutant $\triangle I V S \nabla G C$ contained a 2-bp insertion (GC) replacing the deleted intervening sequence (AIVS). The oligo primers used for chromosomal DNA analysis are indicated by arrows beneath the corresponding sequence ( $5^{\prime}$ primer) or the sequence to which it hybridized $\left(3^{\prime}\right.$ primer $)$. Methods: recombinant M13 viruses containing the tRNA Leu M. Strobel, and J. Abelson (Newman et al., 1983; Strobel, 1985). The 2.2-kb XhoI-Sal I fragment was originally cloned into the Sal I site of pBR322 (destroying the XhoI site). A 772-bp AluI fragment containing pBR322 sequences, the tRNASUUP3 gene and sequences within the $L E U 2$ coding region was then subcloned into the $S m a$ I site of M13mp8. To regenerate the 2.2-kb yeast fragment, the mutant clones were cleaved at the BstEII site within the $L E U 2$ gene and at the SalI site in the polylinker, and the BstEII-SaII $L E U 2$ fragment inserted. The entire EcoRI-HindIII insert was then subcloned into pUC9. Competent DC5 cells were prepared for transformation from an exponentially growing culture by treatment with $0.1 \mathrm{M}$ lithium acetate (Ito et al., 1983). $10 \mu \mathrm{g}$ of SalI-cleaved plasmid DNA was combined with $50 \mathrm{ml}$ of competent cells and incubated $30 \mathrm{~min}$ at $30^{\circ} \mathrm{C} .0 .4 \mathrm{ml} 40 \%$ polyethylene glycol $3350,10 \mathrm{mM}$ Tris (pH 7.5 ) was added and the mixture vortexed gently. Incubation at $30^{\circ} \mathrm{C}$ for $60 \mathrm{~min}$ was followed by a 5 -min incubation at $42^{\circ} \mathrm{C}$. The cells were collected by microcentrifugation, resuspended in $0.1 \mathrm{ml}$ water and plated onto synthetic complete media minus leucine (Sherman et al., 1983). Colonies were picked and replated on the same media to insure selection of individual colonies. 


\section{(b) Screening of transformants}

The primer extension procedure used to screen the transformants for retention of only the mutant genes is described in Fig. 2. Deletions of 13 ( $43^{\prime}$ IVS), 19 ( $\Delta 5^{\prime}$ IVS), 30 ( $\Delta$ IVSVGC), or 32 ( $\Delta$ IVS) bp from the IVS were identified by cleavage of the genomic DNA at a TaqI site near the $3^{\prime}$ terminus of the gene and extension of a radiolabeled oligo ( $5^{\prime}$ primer) across the IVS to the cleavage site (Fig. 2, panel A). In all cases the lengths of the major extension products conformed to those expected for the WT or deleted DNAs. Similarly, the presence of point mutations that created or destroyed restriction sites could be confirmed by cleavage with the diagnostic enzyme and extension of the primer to the site in question (Fig. 2, panel B). These analyses can be performed with DNA from $1 \mathrm{ml}$ of stationary yeast culture, thus facilitating the preparation of genomic DNA from large numbers of transformants. Further, gene replacement can be distinguished from retention of both genes or insertion of multiple genes. Of the 72 colonies examined, 54 retained only the altered tRNA gene and 16 contained only the WT copy. In the single case where both the mutant and WT genes were retained, replating under leucine selection gave subisolates that had either lost one of the copies or retained both ( $\Delta 3^{\prime}$ IVS-1a vs. 1 b). One isolate also seemed to contain two or more copies of the mutant gene ( $\triangle \mathrm{IVS} \nabla \mathrm{GC}-1$ vs. -2 ) that were not lost on replating. Only colonies containing a single copy of the altered tRNA gene were chosen for further analysis.

\section{(c) Fidelity of insertion}

Because the linearized plasmid DNA used for the transformations contained vector sequence at one terminus there was some concern as to whether the cloned genes had discretely replaced the chromosomal copies with concomitant elimination of the vector DNA. Although Southern (1975) analysis gave WT restriction endonuclease products for 14 of the 15 transformants characterized (not shown), more detailed analysis was performed by using the primer extension assay described in Fig. 3. Absence of the EcoRI site of the pUC9 polylinker and reacquistion of the $X h o I$ site at the correct position relative to the primer hybridization site indicated that gene replacement had occurred by recombination between the mutant tRNA ${ }^{\text {Leu }}$ genes and the $X h o I$ site.

\section{(d) Sequence analyses}

To verify that each of these isolates contained the correct tRNA SUP $_{\text {Lu3 }}^{\text {Lu }}$ mutations, extensions were performed on each gene from both the $5^{\prime}$ and $3^{\prime}$ primers in the presence of $2^{\prime}, 3^{\prime}$-ddNTPs. Examples of the resulting sequence data are shown in Fig. 4. In every case only the expected mutations were found, although minor reverse transcription stop sites prevented unambiguous assignments at several positions in the gene unless both strands of the DNA were analyzed. These sites appear faintly in the dNTP lanes in Fig. 4 and are indicated to the right of each panel. While major stop sites outside and at the end of the gene (positions 124-127) also appear in extensions on cloned DNA (not shown), it is interesting to note that the sites within the genes appear primarily in the chromosomal gene templates and vary in position and intensity depending on the particular mutation present. The source of the chromosome-specific sites is unknown, but it is possible that they represent partial cleavage by endogenous endonucleases and reflect the accessibility of the DNA sequences in vivo. Footprinting experiments using exogenous DNA cleavage reagents are currently under way in whole cells and nuclei to address this question.

\section{(e) General applications}

In these experiments we screened non-selectable loci for small sequence changes by oligo extension to altered restriction sites. While this might have been accomplished for these mutants by more conventional blotting techniques, primer extension allows more detailed analyses when examining short segments of DNA. For example, deletions of a single nt can be distinguished because of the high resolution PA gels used to analyze the extension products. In addition the identification of the base transitions is not dependent on changes in restriction sites, since the DNA sequence can be determined directly by ddNTP chain termination. Other methods have recently been developed for determining genomic DNA sequences through base specific chemical 

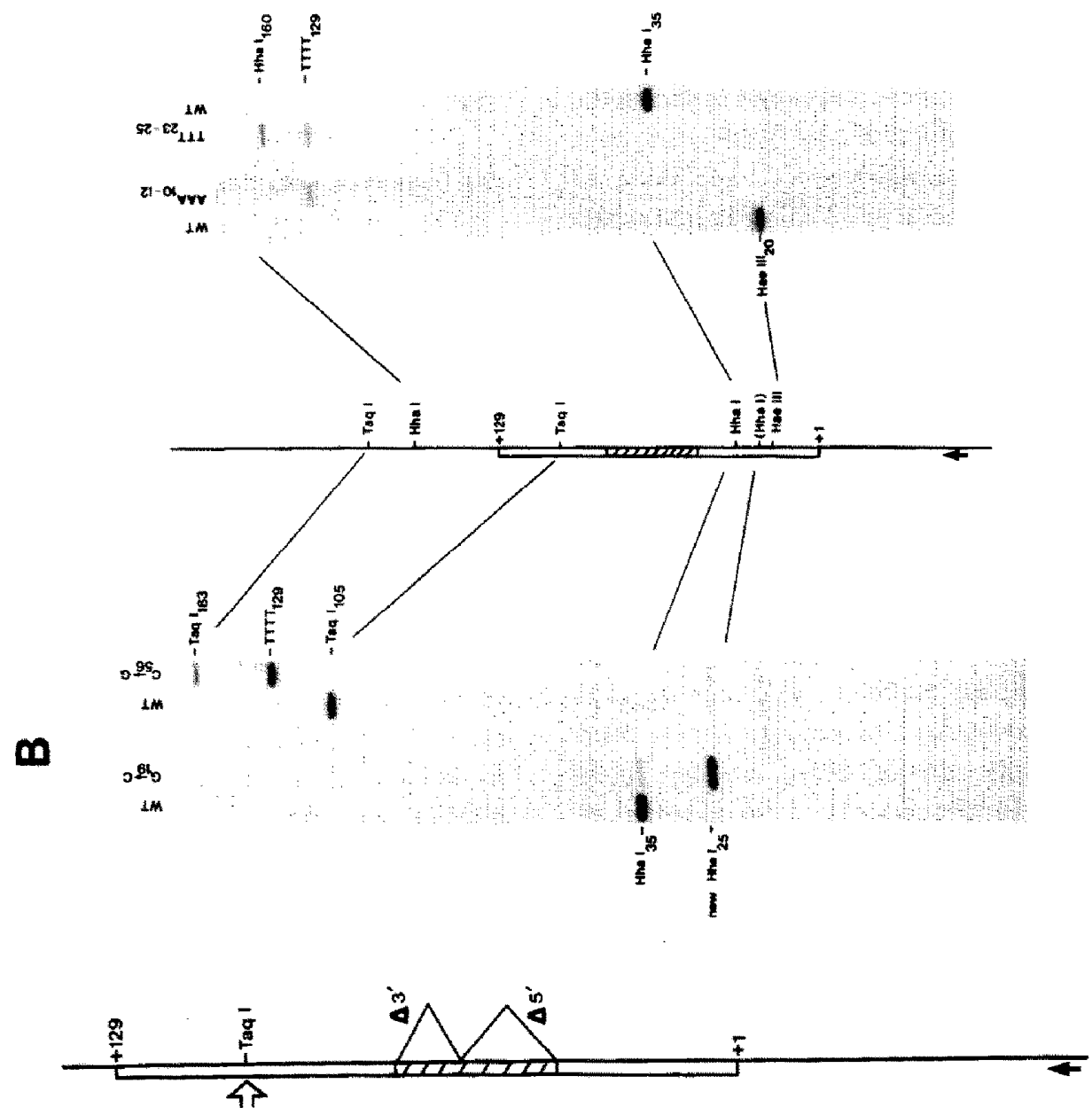

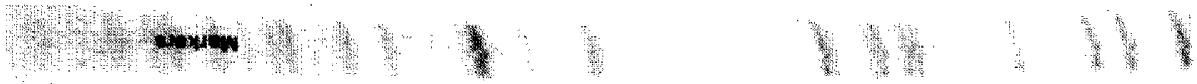

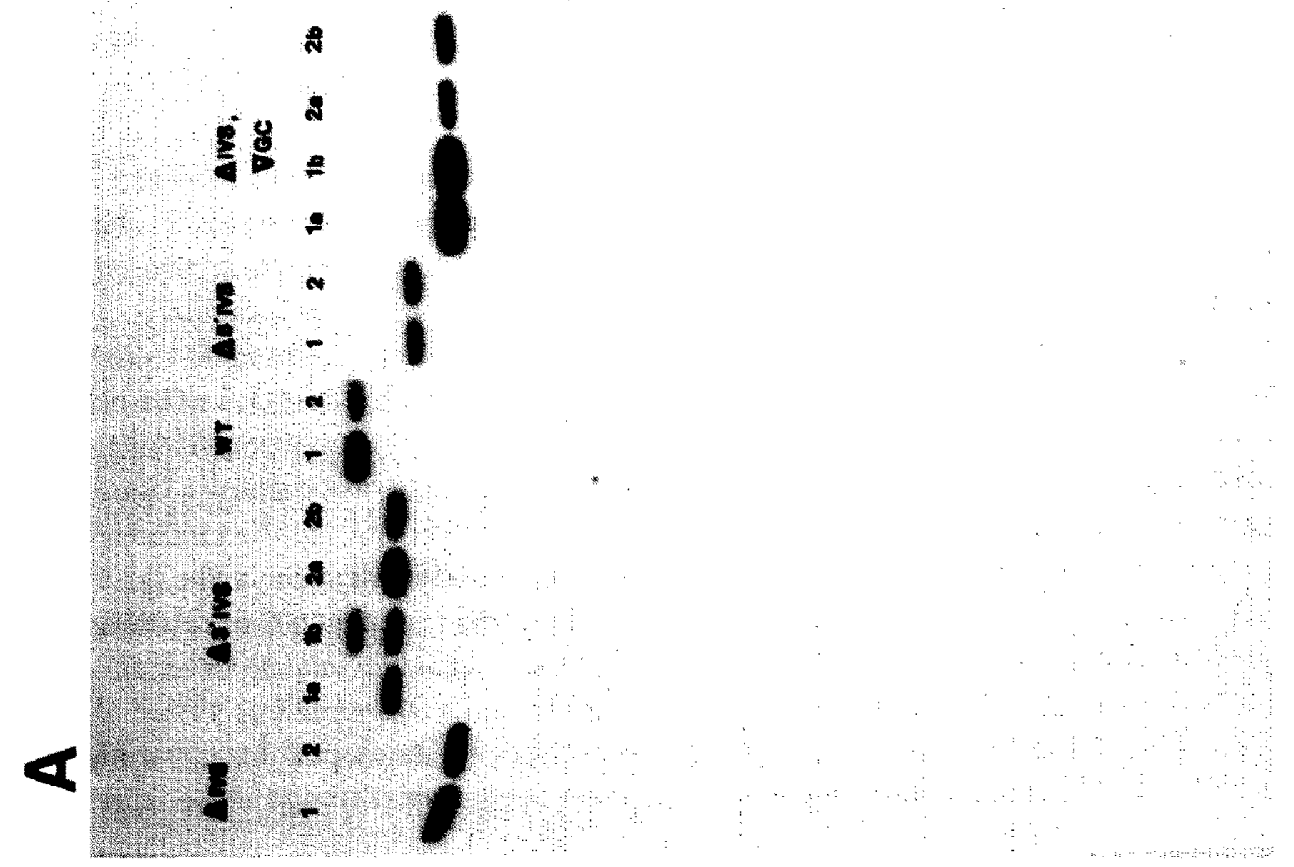


cleavage (Church and Gilbert, 1984) and for identifying the sites of small mutations through heteroduplex mismatches (Meyers et al., 1985a,b). The alternative techniques described here can, by contrast, be performed with the simplicity of standard chain termination methods (Sanger et al., 1977; Sanger and Coulson, 1978; Smith et al., 1979; Wallace et al., 1981; Chen and Seeburg, 1985) and should facilitate routine investigation of DNA sequences in any prokaryotic or small eukaryotic genome.
Higher eukaryotic DNA, however, can be two orders of magnitude more complex than that of yeast and may present problems with respect to both physical limits on the amount of DNA template in the reactions and the ability to anneal oligodeoxynucleotide primers at single sites. To circumvent these problems it may be necessary to enrich the template for the gene of interest. One method that we find yields satisfactory template is to recover DNA restriction fragments containing the gene after size fractionation by electrophoresis through agarose.

Fig. 2. Identification of altered tRNA genes in the transformants. Screening for transformed colonies that had retained only the mutated tRNA ${ }_{3}^{\text {Leu }}$ was performed by a primer extension assay using a total genomic DNA template. The radiolabeled $5^{\prime}$ primer (Fig. 1) was annealed to denatured DNA that had been cleaved with one of the restriction endonucleases listed below. Extension of the primer with AMV reverse transcriptase to the first downstream cleavage site yielded discrete products characteristic of the WT or mutant genes. (Panel A) Deletions from the intervening sequence were identified by extension to the TaqI site at bp 105. Deletions gave products which were shorter than those from the WT gene by 32 ( $\Delta \mathrm{IVS}$ ), 30 ( $\Delta \mathrm{IVS} \nabla \mathrm{GC}$ ), 19 ( $\triangle 5^{\prime}$ IVS) or 13 ( $\Delta 3^{\prime}$ IVS) bp. Analyses on two colonies (lanes 1 and 2 ) of each transformant are shown except for $\Delta 3^{\prime}$ IVS and $\Delta I V S \nabla G C$, where two subisolates (a,b) are shown for each of the original colonies. The darker bands seen with $\triangle I V S \nabla$ GC-1 a and b are not due to differences in the amount of DNA template used and have tentatively been interpreted as indicating multiple copies of the gene. In the case of $\mathbf{\Delta 3}^{\prime}$ IVS, one of the original isolates ( $\left(43^{\prime}\right.$ IVS-1) appeared to have retained both the original and the mutant copies. Replating of this isolate produced colonies which either still retained both copies ( $43^{\prime}$ IVS-1b) or had lost one of the genes ( $43^{\prime}$ IVS-1a; more extensive analysis showed that the WT and mutant genes were lost with approximately equal frequency). The relative positions of the $5^{\prime}$ primer (solid arrow), the tRNA $3^{\text {Leu }}$ gene, the intervening sequence (hatched) and the TaqI cleavage site (open arrow) are indicated. (Panel B) Mutations which created or destroyed restriction sites were analysed by extension of the $5^{\prime}$ primer on genomic DNA that had been digested with the diagnostic enzyme. In each case lanes are shown in which either the mutated or WT DNA was retained in the transformant. The diagram in the center shows the positions of the diagnostic restriction sites and the next downstream site (up to +400 ) for each enzyme. Changes in restriction sites are: $\mathrm{G}_{19} \rightarrow \mathrm{C}$ creates Hhal site at position $25, \mathrm{C}_{56} \rightarrow \mathrm{G}$ destroys a TaqI site at position 105, AAA $A_{10-12}$ destroys a HaeIII site at position 20 and $\mathrm{TTT}_{23-25}$ destroys a $H$ haI site at position 35 . The relatively light band at position 35 in the $C_{19} \rightarrow \mathrm{G}$ lane was not reproducible and was presumed to arise from incomplete digestion with $H h a$ I. Retention of both the WT and mutant genes would have been expected to show roughly equimolar bands at positions 25 and 35 . Strong reverse transcriptase stop sites appear at the poly( $T$ ) transcription terminator and several other sites surrounding the gene (see Figs. 3 and 4 ) in both genomic and purified DNA templates. These could not be avoided by using another enzyme for the extensions since neither the Klenow fragment of DNA polymerase I nor MLV reverse transcriptase functioned well under the conditions required to insure unique priming. Methods: DNA was prepared from $1 \mathrm{ml}$ stationary yeast culture by standard procedures (Sherman et al., 1983). Mutants were identified by cleaving the purified genomic DNA with Taq I (for deletion mutants) or with restriction endonucleases that would recognize sites that wcre cither crcated or destroyed by mutagencsis (Fig. 1). $0.5-0.7 \mu \mathrm{g}$ of this DNA was incubated in a $10-\mu 1$ volume for $5 \mathrm{~min}$ at $95^{\circ}-100^{\circ} \mathrm{C}$ with approx. $50000 \mathrm{dpm}$ of radiolabeled $5^{\prime}$ or $3^{\prime}$ oligo (Fig. 1). The primer was labeled with $\left[\gamma_{-}{ }^{32} \mathrm{P}\right] \mathrm{ATP}$ and T4 polynucleotide kinase to a specific radioactivity of $5000 \mathrm{Ci} / \mathrm{mmol}$. Primers of $15-17 \mathrm{nt}$ were used because the temperature for unique hybridization with total genomic DNA is $42^{\circ}-52^{\circ} \mathrm{C}$, allowing the hybridization and primer extension reactions to be performed at the same temperature. $2 \mu 1$ of $10 \times$ AMV reverse transcriptase buffer [0.5 M Tris ( $\mathrm{pH} \mathrm{8.3),} 0.4 \mathrm{M} \mathrm{KCl}, 0.01 \mathrm{M}$ dithiothreitol, $0.06 \mathrm{M} \mathrm{MgCl}_{2}$ ] was then added and the mixture incubated at $50^{\circ} \mathrm{C}$ for $30 \mathrm{~min}$. $7 \mu 1$ of a dNTP mixture $(0.625 \mathrm{mM}$ each dATP, dCTP, dGTP, dTTP) and $1 \mu 1$ of AMV reverse transcriptase (4 units, Life Sciences, Inc.) were then added and the reaction was continued for $20 \mathrm{~min}$ at $50^{\circ} \mathrm{C}$. Reactions were terminated by the addition of $4 \mu 1$ stop mix [0.1 M EDTA ( $\mathrm{pH} 8.0$ ), $2 \% \mathrm{SDS}, 1 \mathrm{mg} / \mathrm{ml}$ proteinase $\mathrm{K}$ (Beckman)] and further incubated at $50^{\circ} \mathrm{C}$ for 90 min. The DNA was recovered by ethanol precipitation, resuspended in loading buffer $(95 \%$ deionized formamide, $10 \mathrm{mM}$ EDTA, $0.1 \%$ xylene cyanol $)$, denatured at $95^{\circ} \mathrm{C}$ for $4 \mathrm{~min}$ and subjected to electrophoresis on 8 or $10 \%$ PA $(0.15 \mathrm{~mm} \times 40 \mathrm{~cm}$ ) sequencing gels (Sanger and Coulson, 1978). Radiolabeled primer extension products were detected by exposure to Kodak XAR5 film with a DuPont Lightning Plus intensifying screen for 16-48 h. Size markers were provided by concomitant electrophoresis of ddATP sequencing reactions performed under the conditions described in Fig. 4 with 5 fmol of cloned, linear tRNA 

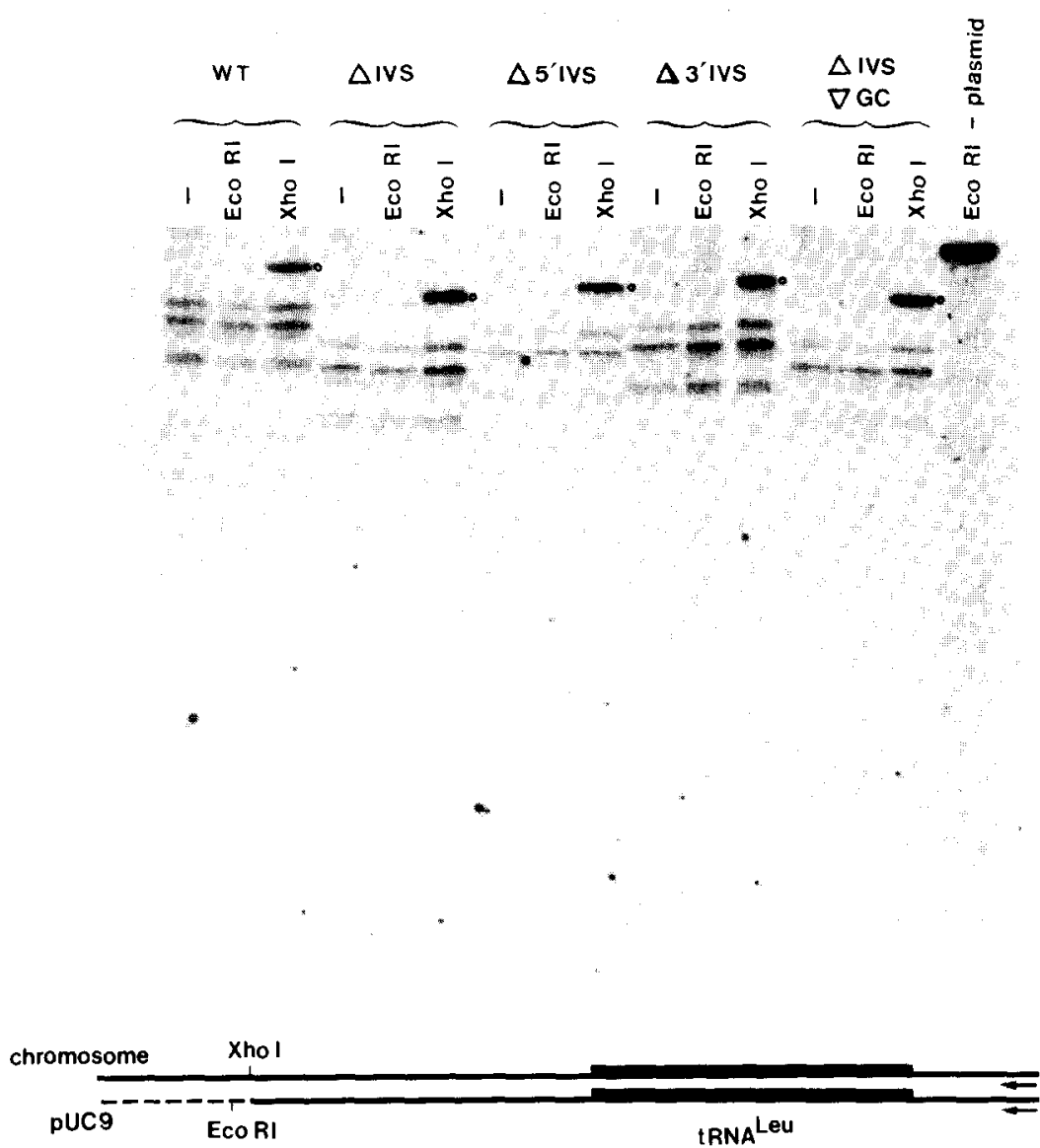

Fig. 3. Fidelity of gene replacement in the yeast chromosome. Primer extension analyses were carried out to insure that no pUC9 DNA had been introduced into the yeast chromosome along with the mutant tRNA genes. Total DNA from the DC5 parent strain (WT lanes) or the transformants was cleaved with either $E c o$ RI or XhoI. In each case, uncut genomic DNA (" - 'lanes) was also used as a template to identify the bands due to reverse transcription stop sites in the sequences upstream from the tRNA gene. As shown schematically at the bottom of the figure, the radiolabeled 3' oligo primer (arrows) was hybridized to the denatured yeast DNA and extended as described in Fig. 2. If the mutant tRNA genes were inserted into chromosome III by recombination between the XhoI site and the tRNA gene, the DNA would contain the XhoI site, but not the EcoRI site from the pUC9 polylinker. In the examples shown, only XhoI-specific extension products (marked with open circles) appear in addition to the ubiquitous primer extension stops. In the deleted genes al extension products are shorter than those from the WT gene by an amount consistent with the size of the deletion. The extension product arising from cleavage of a $\mathrm{pUC9}$ clone (containing no deletion) with $E c o \mathrm{RI}$ is shown in the right-most lane.

Although this ultimately proved unnecessary for our purposes, greater than 50 -fold enrichment could be accomplished for the tRNA ${ }^{\text {Leu }}-L E U 2$ fragment by a single round of cleavage and isolation. Such a step might also serve to separate multicopy genes or polyploid alleles by taking advantage of restriction site polymorphisms. Direct genomic sequence analysis in any organism should therefore be limited only by the availability of sufficient genomic DNA and the ability to enrich for unique loci.

\section{ACKNOWLEDGEMENTS}

We are indebted to Marjorie Strobel, Andrew Newman, and John Abelson for gifts of materials, to Claire Evans, Alexandra Krikos, and John Pringle for helpful discussions and to Timothy Geddes and Robin Childress for technical assistance. This work was supported in part by grant PCM83-02828 from the National Science Foundation, Institutional Grant IN-40X to The University of Michigan from the American Cancer Society and research grants from the Biomedical Research Council, the Rackham Graduate School, and the Phoenix Memorial Project at the University of Michigan. 

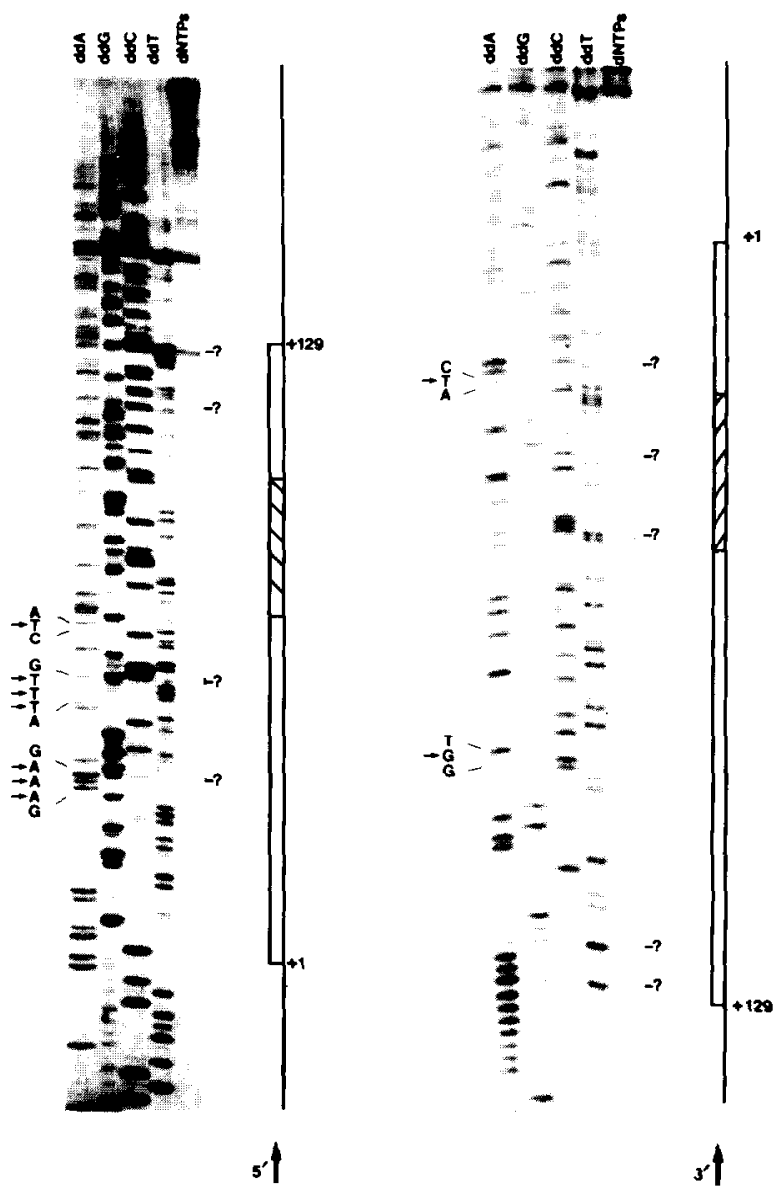

Fig. 4. Chain termination sequence analysis. Examples are shown of direct sequence analysis of genomic DNA using either the $5^{\prime}$ (left) or $3^{\prime}$ (right) oligo primer. In the left panel the DNA from a transformant carrying the $\mathrm{AAA}_{10-12}, \mathrm{TTT}_{23-25}$ and anticodon $A \rightarrow T$ alterations was sequenced with the $5^{\prime}$ primer. In the right panel, the $3^{\prime}$ primer is used to sequence DNA containing the $\mathrm{C}_{56} \rightarrow \mathrm{G}$ and anticodon $\mathrm{A} \rightarrow \mathrm{T}$ transitions. In each panel the four sequencing lanes are accompanied by a lane showing extension with only dNTPs. Extension stop sites that cause ambiguities in the tRNA gene sequence are denoted by question marks. Scquences across mutations (indicated by small arrows to the left of the sequence) are shown on the left margin of each panel and correspond to the strand shown in Fig. 1. The only mutation coinciding with an ambiguous position (third base in $\mathrm{AAA}_{\text {10-12 }}$ ) was confirmed to be correct by sequence data from the opposite strand (not shown). The positions of the tRNA gene exon (open bar) and intron (hatched bar) regions with respect to the sequence are drawn on the right margin of each panel. Methods: The primer extension assay (Fig. 2) was used to directly sequence the genomic copy of the tRNA SUP $53^{\text {Leu }}$ gene by making the following modifications. 10-15 $\mu \mathrm{g}$ of EcoRI-cleaved genomic DNA was used per reaction and the $\mathrm{DNTP}$ mixtures contained a $2^{\prime}, 3^{\prime}$-dNTP ( $20 \mu \mathrm{M}$ for ddATP and ddGTP, $10 \mu \mathrm{M}$ for ddCTP and ddTTP) and a reduced concentration of the corresponding dNTP $(62.5 \mu \mathrm{M})$. Increasing the amount of template DNA resulted in increased frequency of premature chain termination and decreased electrophoretic resolution.

\section{REFERENCES}

Andreadis, A., Hsu, Y..P., Kohlhaw, G.B. and Schimmel, P.: Nucleotide sequence of yeast $L E U 2$ shows 5 '-noncoding region has sequences cognate to leucine. Cell 31 (1982) 319-325.

Chen, E.Y. and Seeburg, P.II.: Supercoil sequencing: a fast and simple method for sequencing plasmid DNA. DNA 4 (1985) $165-170$.

Church, G.M. and Gilbert, W.: Genomic sequencing. Proc. Natl. Acad. Sci. USA 81 (1984) 1991-1995.

Engelke, D.R., Gegenheimer, P. and Abelson, J.: Nuclcolytic processing of a tRNA ${ }^{\text {Arg }}$-tRNA ${ }^{\text {Asp }}$ dimeric precursor by a homologous component from Saccharomyces cerevisiae. J. Biol. Chem. 260 (1985) 1271-1279.

Ito, H., Fukuda, Y., Murata, K. and Kimura, A.: Transformation of intact yeast cells treated with alkali cations. J. Bacteriol. 153 (1983) 163-168.

Meyers, R.M., Lumelsky, N. and Maniatis, T.: Detection of single base substitutions in total genomic DNA. Nature 313 (1985a) 495-498.

Meyers, R.M., Lumelsky, N. and Maniatis, T.: A general method for saturation mutagenesis of cloned DNA fragments. Science 229 (1985b) 242-246.

Newman, A.J., Ogden, R.C. and Abelson, J.: tRNA gene transcription in yeast: Effects of specified base substitutions in the intragenic promoter. Cell 35 (1983) 117-125.

Reed, C.R. and Leibman, S.W.: New amber suppressors in Saccharomyces cerevisiae. Genetics 91 (1979) 5102.

Rothstein, R.J.: One-step gene disruption in yeast. Methods Enzymol. 101 (1983) 202-210.

Sanger, F. and Coulson, A.R.: The use of thin acrylamide gels for DNA sequencing. FEBS Lett. 87 (1978) 107-110.

Sanger, F., Nicklen, S. and Coulson, A.R.: DNA sequencing with chain terminating inhibitors. Proc. Natl. Acad. Sci. USA 74 (1977) 5462-5467.

Scherer, S. and Davis, R.W.; Replacement of chromosome segments with altered DNA sequences constructed in vitro. Proc. Natl. Acad. Sci. USA 76 (1979) 4951-4955.

Sherman, F., Fink, G.R. and Hicks, J.B.: Methods in Yeast Genetics. Cold Spring Harbor Laboratory, Cold Spring Harbor, NY, 1983, pp. 62, 119B.

Shortle, D., Novick, P. and Botstein, D.: Construction and genetic characterization of temperature-sensitive mutant alleles of the yeast actin gene. Proc. Natl. Acad. Sci. USA 81 (1984) 4889-4893.

Smith, M., Leung, D.W., Gillam, S., Astell, C.R., Montgomery, D.L. and Hall, B.D.: Sequence of the gene for iso-1-cytochrome c in Saccharomyces cerevisiae. Cell 16 (1979) 753-761.

Southern, E.M.: Detection of specific sequences among DNA fragments separated by gel electrophoresis. J. Mol. Biol. 98 (1975) 503-517.

Strobel, M.: Role of an S. cerevisiae Pre-tRNA Intron: Base Modifications, Splicing and Suppressor IRNA Function. Ph.D. Thesis, University of California, San Diego, 1985. 
Vieira, J. and Messing, J.: The pUC plasmids, an M13mp7derived system for insertion mutagenesis and sequencing with synthetic universal primers. Gene 19 (1982) 259-268.

Wallace, R.B., Johnson, M.J., Suggs, S.V., Miyoshi, K., Bhatt, R. and Itakura, K.: A set of synthetic oligodeoxyribonucleotide primers for DNA sequencing in the plasmid vector $\mathrm{pBR} 322$. Gene 16 (1981) 21-26.

Communicated by M.L. Cultbertson. 